Article

\title{
The European Semester and Parliamentary Oversight Institutions Inside and Outside of the Euro Area
}

\author{
Thomas Winzen \\ Department of Government, University of Essex, UK; E-Mail: thomas.winzen@essex.ac.uk
}

Submitted: 1 February 2021 | Accepted: 6 May 2021 | Published: 13 August 2021

\begin{abstract}
The European Semester is a challenge for national parliaments but also an opportunity to reform domestic oversight institutions. Drawing on data from all member states, this study examines the conditions under which national parliaments use this opportunity. Is Euro area membership a prerequisite for parliamentary adaptation to the European Semester and, if so, which further combinations of conditions account for variation among Euro area countries? The analysis suggests that membership in or close ties with the Euro area and institutional strength constitute necessary conditions for parliamentary adaptation. Combined with other factors - in particular, public debt exceeding the Maastricht criteria-these conditions explain reform in many cases. National parliamentary adaptation to the European Semester thus follows existing institutional divisions constituted by differentiated integration in the Euro area and uneven national parliamentary strength.
\end{abstract}

\section{Keywords}

differentiated integration; economic governance; European Semester; national parliaments

\section{Issue}

This article is part of the issue "Rising to a Challenge? Ten Years of Parliamentary Accountability of the European Semester" edited by Eric Miklin (University of Salzburg, Austria), Aleksandra Maatsch (University of Wroclaw, Poland) and Tomasz P. Woźniakowski (Hertie School, Germany).

(C) 2021 by the author; licensee Cogitatio (Lisbon, Portugal). This article is licensed under a Creative Commons Attribution 4.0 International License (CC BY).

\section{Introduction}

The European Semester is the process through which the EU seeks to ensure member state compliance with its macroeconomic and fiscal rules. Concerns have been raised that this yearly cycle of coordination, monitoring, and assessment, combined with significant enforcement procedures, might curtail the authority of national parliaments. The European Semester might thus lack input legitimacy (Crum \& Merlo, 2020; Dawson, 2015; Lord, 2017). In turn, it has been argued that national parliaments should prioritize attention to EU economic governance (de Wilde \& Raunio, 2018). Against this backdrop, this study examines whether national parliaments adapt to the European Semester by reforming domestic oversight institutions, defined as rights and procedures to scrutinize the government during the Semester process.

The question of whether national parliaments adapt institutionally to the European Semester is rendered complicated by the architecture of economic governance and the diversity of existing parliamentary institutions. Euro area integration is highly differentiated, and the Semester's implications vary accordingly across countries. Yet, the literature on differentiated integration has largely sidestepped any discussion of national parliaments, and research on national parliaments has hardly mentioned differentiated integration (for reviews, see Holzinger \& Schimmelfennig, 2012; Winzen, 2021; but see Genovese \& Schneider, 2020). Specific research on the European Semester, moreover, disagrees on the effect of Euro area membership on national parliaments (Hallerberg et al., 2018; Rasmussen, 2018). Similarly, regarding existing institutions, it has been argued that strong existing oversight in EU or budget matters could encourage adaptation to the Semester but also render Semester-specific adaptation superfluous (Dimitrakopoulos, 2001; Kreilinger, 2018; Maatsch, 2017; Rozenberg, 2017, p. 45). 
My argument starts from the premise that national parliaments consider institutional reform as a response to changes in EU authority (e.g., Raunio \& Hix, 2000). The European Semester, in principle, constitutes an opportunity for reform. However, two further points can be made. First, differentiated integration means that some parliaments are exempt from EU authority, notably the Semester's enforcement procedures, and thus unlikely to consider reform at all. Euro area membership and close institutional ties to the Euro area (explained below) would thus constitute a necessary condition for parliamentary adaptation. Second, even member states for which the Semester is a significant reform opportunity do not necessarily reform oversight procedures. Rather, existing institutions and other party political and economic conditions highlighted in the literature (Dimitrakopoulos, 2001; Raunio, 2005; Winzen, 2017) might be required to motivate reform sufficiently.

Empirically, I examine data on European Semesterspecific reforms of parliamentary oversight institutions in all member states. A qualitative comparative analysis (QCA) is used to assess which combinations of conditions are necessary and sufficient for reform. The main findings include that only a few parliaments have implemented Semester-specific oversight institutions. Euro area membership or close ties to the Euro area via the Fiscal Compact and the Exchange Rate
Mechanism (ERM) are found to be necessary for reform. Institutional strengths-defined by pre-existing institutional rights in EU or budgetary matters-is another necessary condition. These two explanations, combined with a range of other factors, form several sufficient configurations of conditions for reform. Public debt exceeding the Maastricht criteria appears in several of these configurations.

As discussed in the conclusion, these findings add more specific evidence on the role of parliaments in the European Semester than available so far. More broadly, if input legitimacy is understood in terms of parliamentary oversight institutions, a key conclusion is that there is cross-national variation in the input legitimacy of the European Semester. This variation reflects broader institutional differences constituted by uneven parliamentary strength and differentiated integration. The conclusion further highlights different perspectives on the implications of this finding.

\section{Challenges and Opportunities for National Parliaments}

In comparison to earlier fiscal and economic coordination processes, the European Semester has stronger procedures and enforcement mechanisms. As Table 1 shows, the EU conducts country-specific monitoring of

Table 1. The European Semester: Process and enforcement.

\begin{tabular}{|c|c|c|c|}
\hline Phase & Key procedural steps & Countries & Legal bases \\
\hline Nov-Mar & $\begin{array}{l}\text { Surveillance of macro-economic imbalances } \\
\text { Macro-economic scoreboard } \\
\text { Country reviews } \\
\text { Commission economic priorities } \\
\text { European Council economic priorities }\end{array}$ & All & 'Six-pack' (2011). \\
\hline Apr-Jun & $\begin{array}{l}\text { Plans \& recommendations } \\
\text { Structural reform plans ('National Reform Programs') } \\
\text { Fiscal plans ('Stability and Convergence Programs') } \\
\text { Country-specific recommendations by Commission } \\
\text { Council and European Council endorsement }\end{array}$ & All & 'Six-pack' (2011). \\
\hline Sep-Dec & $\begin{array}{l}\text { Budgetary coordination } \\
\text { Assessment of draft budgets against SGP \& CSRs } \\
\text { Commission recommendations, Council debate }\end{array}$ & EA & $\begin{array}{l}\text { 'Six-pack' (2011), } \\
\text { 'Two-pack' (2011), } \\
\text { Fiscal Compact (2013). }\end{array}$ \\
\hline Enforcement & $\begin{array}{l}\text { Macro-Economic Imbalances Procedure (MIP) } \\
\text { Recommendations \& Corrective Action Plan } \\
\text { Non-compliance judgment by RQMV } \\
\text { Sanctions: Deposits and fines by RQMV }\end{array}$ & $\begin{array}{l}\text { Mixed } \\
\text { All } \\
\text { All } \\
\text { EA }\end{array}$ & 'Six-pack' (2011). \\
\hline Enforcement & $\begin{array}{l}\text { Excessive Deficit Procedure (EDP) } \\
\text { Policy recommendations } \\
\text { Decision on inadequate action (QMV) } \\
\text { Economic and Partnership Programmes } \\
\text { Enhanced surveillance \& reporting } \\
\text { Sanctions by RQMV }\end{array}$ & $\begin{array}{l}\text { Mixed } \\
\text { All } \\
\text { All } \\
\text { EA } \\
\text { EA } \\
\text { EA }\end{array}$ & $\begin{array}{l}\text { Art. } 126 \text { \& } 139 \text { TFEU, } \\
\text { 'Six-pack' (2011), } \\
\text { 'Two-pack' (2011), } \\
\text { Fiscal Compact (2013). }\end{array}$ \\
\hline
\end{tabular}

Notes: EA: Euro area; RQMV: Reverse Qualified Majority Voting. Source: Own compilation based on the legal instruments cited in the column 'Legal bases'. 
macro-economic conditions, requests reform and fiscal plans before national budgets are presented to national parliaments, and makes country-specific recommendations for compliance with the Stability and Growth Pact (SGP) and macro-economic stability goals. Euro area member states additionally submit draft budgets for EU scrutiny. EU recommendations for macro-economic reform and compliance with the SGP can be enforced with a new Macro-Economic Imbalances Procedure (MIP) and a reformed Excessive Deficit Procedure (EDP), which can result in enhanced surveillance, financial deposits and financial sanctions unless opposed by a qualified majority of member states. However, the sanctions only apply to the Euro area. Finally, since 2021, to access funding under the EU's Covid-19 Recovery and Resilience Facility, member states have to submit reform plans reflecting country-specific priorities identified in the European Semester, which are then rated by the European Commission in light of the European Semester's goals.

The challenges that the European Semester poses for national parliaments have received significant attention (Crum \& Merlo, 2020; Dawson, 2015; Lord, 2017). In brief, the concerns raised are threefold. First, the rules accompanying the Semester, including the reinforced SGP and the prescriptions of the Fiscal Compact, create quasi-constitutional constraints for the policy choices available in parliaments and other arenas. Not all observers agree that the wider economic governance rules, such as the Fiscal Compact, should be treated together with the European Semester. Yet, the Semester process makes regular reference to these instruments and integrates sanctioning mechanisms related to these instruments. Second, the Semester creates new EU-level processes and activities, including reporting, deliberation and negotiation, and voting on economic performance from which parliaments are excluded, but regarding which they could demand improved oversight. Third, the European Semester has repercussions for existing parliamentary oversight. It requires various documents and commitments from governments early in the budgetary process, which they-in the shadow of potential sanctions and funding decisions under the Covid-19 response facility-could in turn cite to restrict the scope of parliamentary budget decisions and to deflect accountability to the EU.

There are, however, opportunities for national parliaments to address these challenges. First, parliaments have created the Interparliamentary Conference on Stability, Economic Coordination and Governance in the European Union to 'contribute to ensuring democratic accountability in the area of economic governance and budgetary policy in the EU, particularly in the EMU' (Interparliamentary Conference on Stability, Economic Coordination and Governance in the European Union, 2015, articles 2.1 and 4.2). Second, parliaments can adapt domestic oversight institutions vis-à-vis the governments in relation to the European Semester
(Hallerberg et al., 2018; Kreilinger, 2018; Rasmussen, 2018; Rittberger \& Winzen, 2015). Whereas the effectiveness of the Interparliamentary Conference remains debated, the second path, which is the focus here, is wellestablished in EU governance and might be relevant for the European Semester as well.

\section{Differentiated Euro Area Membership and Parliamentary Adaptation to the European Semester}

Can parliaments be expected to adapt domestic oversight institutions to the European Semester? The literature on national parliamentary adaptation to the EU highlights conditions under which parliamentary actorsmainly political parties-consider reforms of oversight. This literature expects that changes in EU authority encourage reform discussions, either because parliamentary actors belief that EU authority creates a democratic deficit (Rittberger, 2003), or because they seek to avert losses of their own authority (Benz, 2004; Saalfeld, 2005). Yet, changes in EU authority do not necessarily result in changes in oversight institutions but are best seen as 'reform opportunities' that enable but do not determine change (Winzen, 2017, pp. 73-75). To understand parliamentary adaptation, we thus need to ask, first, whether the European Semester constitutes a reform opportunity and, second, which other factors might be required to motivate reforms sufficiently. This section discusses the first question.

At face value, the European Semester could plausibly be expected to trigger parliamentary reform debates. While it remains contested whether the Semester changes the distribution of authority between the EU and the member states, it enhances the intensity of economic policy coordination, creates new monitoring mechanisms, strengthens the enforcement of (reinforced) economic and fiscal rules, and, since 2021, is linked to financial incentives under the EU's Covid-19 response. Supranational institutions have also gained some influence according to some studies (Bauer \& Becker, 2014; van der Veer \& Haverland, 2018). According to the standards of the literature (e.g., Börzel, 2005), these developments constitute an increase in authority and a plausible reason for parliamentary actors to examine the need for reform.

However, the literature on parliamentary adaptation has paid less attention to differentiated integration (Holzinger \& Schimmelfennig, 2012; Schimmelfennig et al., 2015). Rather, changes in EU authority have been assumed to be the same for all member states and, therefore, not a promising explanation for cross-national variation. The literature on differentiated integration highlights that this need not be the case as member states might be exempted or excluded from EU authority in different policy regimes. By implication, the incentives for parliamentary actors to reform oversight institutions might vary across member states. Genovese and Schneider (2020) argue along these lines that Euro area 
parliaments faced greater pressure to enhance scrutiny in response to the 2007-2008 financial crisis.

The European Semester is a prominent example of variation in EU authority due to differentiated integration. First, differentiation in Euro area membership is closely linked with the authoritativeness of the Semester process given that the main enforcement mechanisms do not apply to countries without the Euro. Second, some Euro area outsiders have close ties to the Euro. Denmark participates in the ERM, with its currency pegged to the Euro, and has ratified the Fiscal Compact. This might lend the European Semester greater importance in Denmark than in countries without the Euro. Latvia and Lithuania also participated in the ERM before adopting the Euro in 2014 and 2015. Additionally, Bulgaria and Romania were not in the ERM in the period covered here but ratified the Fiscal Compact fully (Romania) or partly (Bulgaria).

Due to the differentiation of the Euro area, it seems likely that parliamentary reforms will be considered in only some member states. In the countries that are subject to the most authoritative Semester processesnotably, potential sanctions-parliamentarians have the strongest reasons to examine the need for oversight procedures due to both mechanisms emphasized in the literature-to avert losses of authority and remedy perceived parliamentary deficits. Parliamentarians in countries that are not in the Euro but have close ties to the Euro area might also pay more careful attention to the Semester. Even if they do not face sanctions themselves, they have greater stakes in the policies of the Euro area countries and might deem oversight over their governments' strategies during the Semester important. In contrast, interest in parliamentary reform is likely to remain limited in countries outside of the Euro area and without close ties to it. In these countries, the Semester is not entirely irrelevant but appears rather similar to EU soft law processes, which have been found to raise little parliamentary attention (de Ruiter, 2010).

\section{Variation in Parliamentary Adaptation Within the Euro Area}

We have argued so far that the European Semester might enable reform discussions in the Euro area and closely affiliated countries but might motivate reform sufficiently only in combination with other conditions. The literature on national parliaments in the EU highlights several possible conditions. The strength of pre-existing institutions has been seen as shaping the need for reform where institutional deficits exist but also as constraining the range of reforms considered appropriate by domestic actors in light of institutional traditions (Benz, 2004; Dimitrakopoulos, 2001). In turn, Euroscepticism, for example among governing parties, has been thought to motivate demands to protect and reinforce the authority of national parliaments (Winzen et al., 2015). These general arguments might help explain parliamentary adaptation to the European Semester. Additionally, since the European Semester is about macro-economic monitoring, the economic context of parliamentary reform requires attention.

Two institutional conditions will be examined. First, parliaments with strong rights in the domestic budgetary process - the area most affected by the European Semester-might extend their position to the Semester process (Kreilinger, 2018; Maatsch, 2017; Rittberger \& Winzen, 2015). Parliamentarians of governing parties accustomed to being formally consulted on budget decisions might seek to protect this prerogative. Strong budget rights could also lead parliamentarians across parties to believe that the European Semester creates a democratic deficit. Second, for similar reasons, parliaments with strong oversight institutions in EU affairs might seek to uphold this strong role in the area of economic governance (Rittberger \& Winzen, 2015). Yet, the implications of institutions are not unambiguous. Some studies highlight that they might render adaptation to the European Semester unnecessary. For example, the Finish parliament concluded that existing EU affairs oversight mechanisms were sufficiently broad in legal and practical terms to encompass the Semester (Kreilinger, 2018, p. 330; Rozenberg, 2017, p. 45). The positions in the literature are potentially compatible. Institutional strength might make adaption to the European Semester possible-in the sense of a necessary condition-but need not result in reforms.

At the level of political parties, it has been argued that parties opposed to the European Parliament or European integration more generally are most likely to demand strong rights for national parliaments (Winzen et al., 2015). In the case of the European Semester, perceptions of the European Parliament might not matter because this institution's involvement in the process remains limited (Crum, 2018; Fasone, 2014; Fromage, 2018). Yet, parties that oppose European integration might see value in empowering national parliaments to underline their belief that budgetary authority should reside at the national level. Where Eurosceptic parties hold government authority, parliamentary adaptation to the European Semester becomes a plausible outcome.

Finally, parliamentary adaptation might depend on a country's economic situation (Genovese \& Schneider, 2020; Kreilinger, 2018, p. 331; Rittberger \& Winzen, 2015, p. 443). The mechanism is that certain economic conditions put a country at risk of entering the MIP or EDP, which implies enhanced monitoring and the possibility of sanctions. This prospect might enhance parliamentary interest in oversight of the government's conduct during the Semester including, for example, its efforts to avert entering the MIP and EDP. Which economic conditions matter? The analysis here focuses on public debt. The EDP depends on the Maastricht convergence criteria including public debt. The MIP relies on a broader assessment in the context of the European Commission's 
annual Alert Mechanism Report, but debt is one important indicator.

\section{Data and Operationalization}

This study analyzes data on national parliamentary oversight institutions for the European Semester (Rittberger \& Winzen, 2015; Winzen, 2021). These data stem from examining national constitutions, legislation, parliamentary rules of procedure, and other parliamentary documents and, if primary sources were unavailable, academic literature, to identify formal oversight institutions in national parliaments in relation to the European Semester on a yearly basis. Parliamentary adaptation to the European Semester can be divided into three categories (Table 2). The first comprises parliaments in which no specific oversight institutions have been created. The second category captures selective reforms, such as when parliaments are entitled to receive National Stability and Reform Programmes before submission to the EU, but no further rights or procedures exist. In these parliaments, the rules of procedure and other sources make only passing reference to the Semester. A typical example is Austria, where existing legislation and parliamentary rules of procedure rarely mention the European Semester except that they require that the Stability Programme is brought to the parliament's attention. The third group encompasses parliaments that have created detailed oversight procedures and rights. For example, the Danish parliament has created a comprehensive 'National Semester' to mirror the European Semester and to provide procedures for continuous monitoring of the government (Folketinget, 2013).

Table 3 summarizes the operationalization of the conditions employed in the analysis. The data used are in line with previous studies. It should be noted, however, that parliamentary budget authority proves challenging to measure. An often-used index by Wehner (2006), based on OECD data from 2003, is now dated and misses $10 \mathrm{EU}$ member states ( 6 from the Euro area). The analysis here relies on the more recent OECD Parliamentary Budgeting Practices Database (OECD, 2018). The OECD surveyed Parliamentary Budget Officials from 34 countries to specify characteristics of the budgetary process. For this study, relevant questions were selected and aggregated, as detailed in Appendix 1 in the Supplementary File, to form an index of parliamentary budget authority. A key advantage is that this measure includes all but 6 member

Table 2. Adaptation of parliamentary oversight institutions to the European Semester.

\begin{tabular}{ll}
\hline Category & Description \\
\hline No reforms (0) & No or minor oversight institutions. \\
Moderate reforms (0.5) & $\begin{array}{l}\text { Oversight procedures and rights in some steps of the European Semester. Typically, } \\
\text { parliament receives the Stability/Convergence and Reform Programmes at the same } \\
\text { time as or before the EU. }\end{array}$
\end{tabular}

Strong reforms (1)

Extensive governmental reporting obligations or participation in decisions on important documents.

Source: Adapted from Rittberger and Winzen (2015) and Winzen (2021).

Table 3. Operationalizing the conditions in the analysis.

\begin{tabular}{|c|c|}
\hline Condition & Explanation \\
\hline Euro area membership. & Formal membership in the Euro area. \\
\hline Close ties to the Euro area. & $\begin{array}{l}\text { Countries that are in the Exchange Rate Mechanism (ERM) or ratified the Fiscal } \\
\text { Compact fully or partly. }\end{array}$ \\
\hline $\begin{array}{l}\text { Oversight institutions in EU affairs } \\
\text { (Winzen, 2012, 2021). }\end{array}$ & $\begin{array}{l}\text { An index of EU-specific oversight institutions including the existence of European } \\
\text { Affairs Committees, a formal role of sectoral committees, obligatory explanatory } \\
\text { memoranda, a scrutiny reserve, and mandating rights. Range: } 0-1 \text {. }\end{array}$ \\
\hline $\begin{array}{l}\text { Parliamentary budget rights } \\
\text { (OECD, 2018). }\end{array}$ & $\begin{array}{l}\text { An index of parliamentary rights and resources in the budgetary process created } \\
\text { based on the OECD Parliamentary Budgeting Practices Database. Appendix } 1 \text { in } \\
\text { the Supplementary File explains the operationalization in detail. }\end{array}$ \\
\hline $\begin{array}{l}\text { Government support for the EU } \\
\text { (Bakker et al., 2015, 2020; } \\
\text { Polk et al., 2017). }\end{array}$ & $\begin{array}{l}\text { Seat-weighted average of government party leaderships' orientations towards } \\
\text { European integration based on Chapel Hill Expert Surveys. Range: } 1 \text { (strongly } \\
\text { opposed)-7 (strongly in favor). }\end{array}$ \\
\hline Public debt (Eurostat). & Government consolidated gross debt as percentage of GDP. \\
\hline
\end{tabular}


states and all but 3 (Cyprus, Malta, and Lithuania) from the Euro area.

The data on adaptation to the European Semester and the remaining conditions will be examined descriptively with a focus on trends and bivariate relationships as well as in a QCA (explained below). For the QCA, the continuous variables have to be dichotomized. The mean was chosen as a threshold for EU oversight institutions, government EU support, and budget authority. The mean divides the data relatively evenly. In the case of budget authority, it also coincides with the largest gap in the data. For public debt, 60 percent was set as the threshold, which reflects the Maastricht convergence criteria.

\section{Bivariate Relationships}

Figure 1 charts parliamentary adaptation to the European Semester over time. 12 parliaments implemented moderate to strong reforms between 2011, the first year of the data, and 2020. All but one reform-in Greece after the country exited the EU's financial aid and conditionality program-occurred in the first years of the Semester, suggesting that a state of institutional stability might have been reached. The overall picture is one of limited institutional adaptation with reforms in a minority of member state parliaments.
How does parliamentary adaptation relate to the possible explanations? Examining bivariate relationships first, it appears that 53 percent of Euro area members compared to 22 percent of countries without the Euro had seen parliamentary reforms by 2019 (Figure 2). In addition, the only countries outside of the Euro area that implemented reforms-Denmark and Bulgariahave close ties to the Euro area via the ERM or Fiscal Compact. What might be most interesting, considering the arguments examined here, is that Euro area membership and close ties to the Euro area together constitute a jointly necessary (but not sufficient) condition for reform. No reforms are observed in countries lacking membership or close ties. Yet, reforms are not always observed in countries with these characteristics.

Figure 3 examines relationships between the other conditions, averaged from 2011-2019, and European Semester adaptation of national parliaments in 2019. Parliaments with strong EU affairs oversight institutions appear to have adapted most to the European Semester, although this relationship is quite tentative. For example, the Finish and German parliaments have strong oversight institutions but no specific Semester rights and procedures. The Greek and Portuguese parliaments implemented some Semester-specific reforms despite having comparatively weak EU affairs institutions. Similarly, there seems to some tendency for

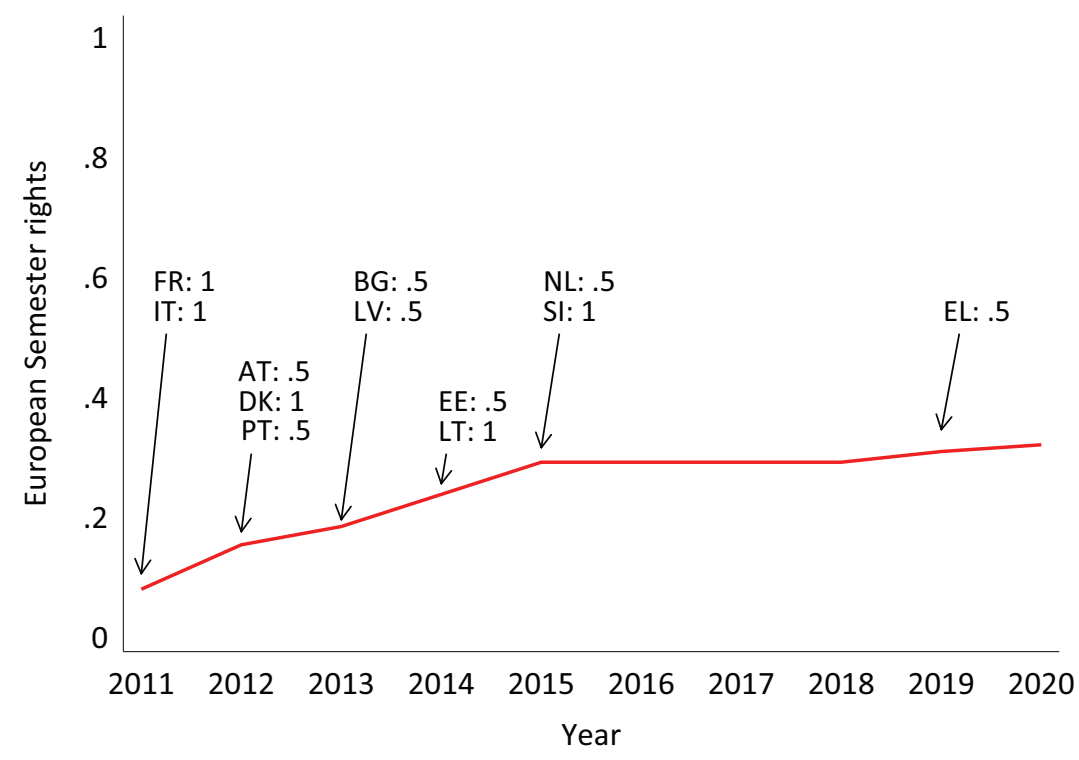

Figure 1. Parliamentary adaptation to the European Semester since 2011. Notes: The figure shows parliamentary adaptation to the European Semester averaged over member states and highlights all observed reforms; The trend rises in 2020 because the United Kingdom (a parliament without formal oversight institutions for the Semester) left the EU.

\section{Euro area member states \\ Member states without the Euro

\begin{tabular}{|c|c|}
\hline & \\
\hline ES oversight institutions & (a \\
\hline
\end{tabular}

Figure 2. Parliamentary adaptation inside and outside of the Euro area in 2019. Notes: The color scheme encodes the values in Table 2: Dark blue $=1$; Light blue $=0.5 ;$ Red $=0$; Countries without the Euro but with close ties to the Euro area via the ERM or ratification of the Fiscal Compact are underlined. Source: Adapted from Winzen (2021). 
a) EU oversight institutions

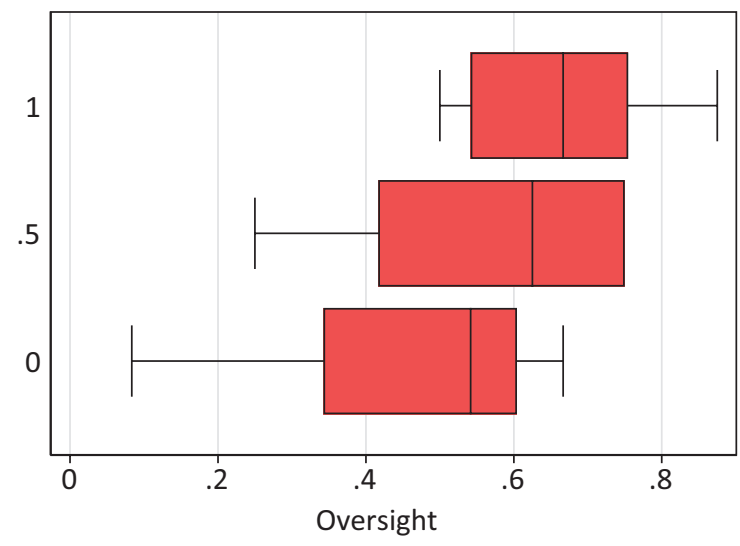

c) Government EU support

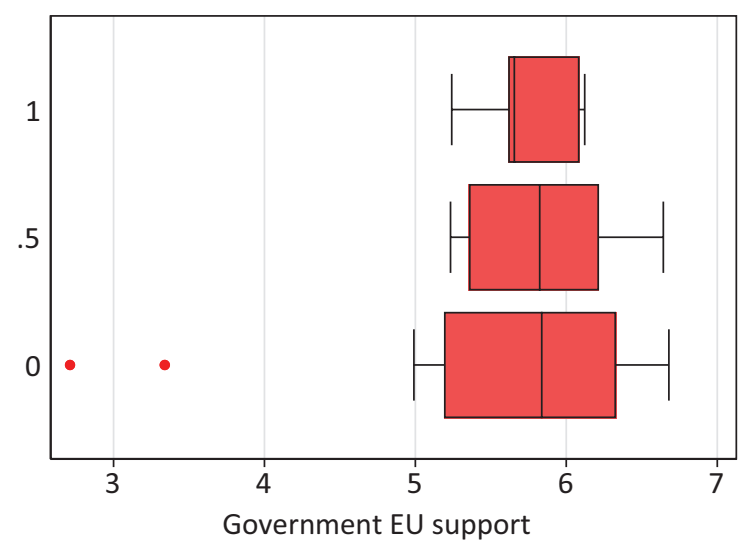

b) Parliamentary budget rights

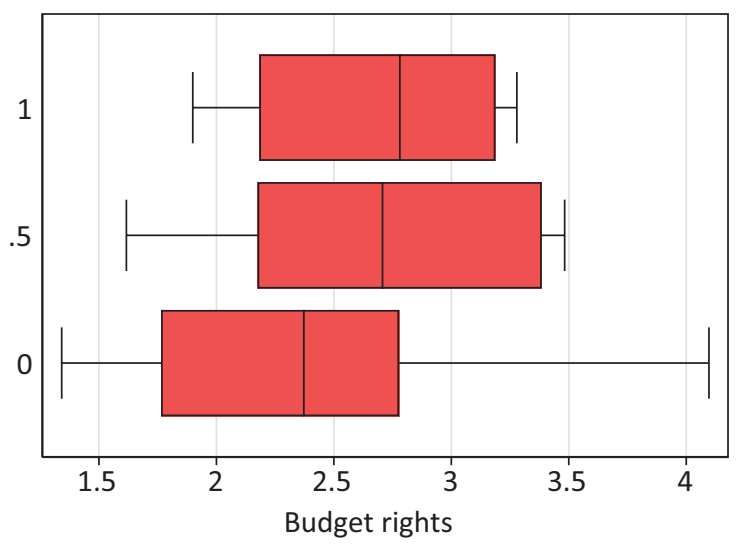

d) Public debt

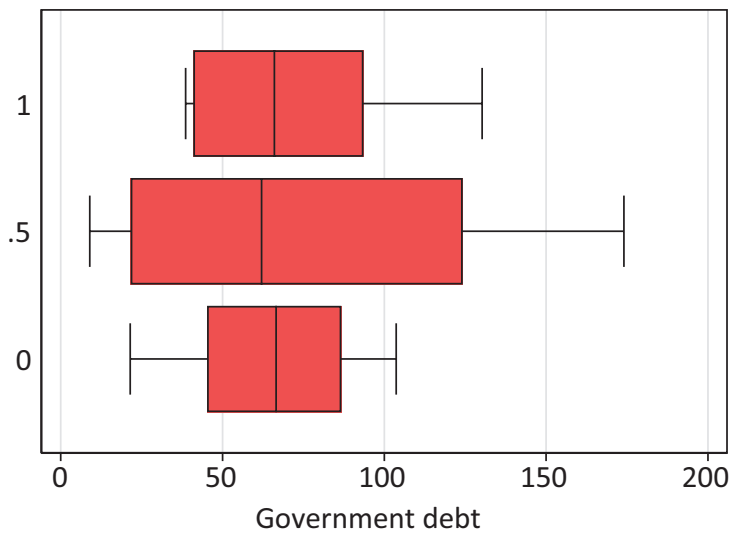

Figure 3. European Semester adaptation in 2019 and explanatory conditions. Notes: The vertical axis shows adaptation to the European semester by 2019: No reforms (0), Moderate reforms (0.5), Strong reforms (1) (see Table 2); The horizontal axis shows average values of the conditions for 2011-2019.

European Semester adaptation to go together with budget rights. The overall picture is one of relatively ambiguous relationships. We can also examine relationships between the dichotomized conditions (see previous section) and adaptation to the European Semester to detect whether their presence or absence might be necessary or sufficient for parliamentary reforms. Yet, this is not case for any individual condition (see Appendix 2 in the Supplementary File).

\section{Paths to Adaptation Within the Euro Area and Closely Linked Countries}

The previous section suggests that membership in the Euro area or having close ties to the Euro area is necessary for the creation of oversight institutions in the European Semester. Yet not all parliaments that meet this condition adapt to the Semester. This section focuses on configurations of conditions that might explain parliamentary adaptation sufficiently. To this end, a QCA is presented, which groups cases based on their characteristics and searches, based on Boolean algebra, for combinations of characteristics that are sufficient for the outcome (Rihoux \& Ragin, 2009). Focusing on the Euro area and countries with close ties (given the absence of reform elsewhere), the outcome of interest is whether parliaments have at least some oversight institutions by 2019. The conditions are as described in the data and operationalization section.

The first step in a QCA is the truth table which shows the cases and configurations of conditions in the analysis (Table 4). Except for two deviant casesDenmark and Spain-the table is free from contradictions. At the same time, most configurations are specific for one or two countries suggesting that paths to European Semester adaptation are relatively idiosyncratic. At first sight, this impression appears to be confirmed in Table 5, which shows minimally sufficient configurations for the positive (moderate or strong oversight institutions) and negative outcome, obtained by minimizing the truth table. We observe several, often complex configurations. Moreover, many conditions appear in paths to positive and negative outcomes, and they do so if they are present and absent.

However, careful examination of Table 5 suggests important insights. Regarding the positive outcome, all paths involve strong institutions in EU affairs or the budget process (albeit not necessarily both). Further analysis 
Table 4. Cases and configurations in the analysis.

\begin{tabular}{|c|c|c|c|c|c|}
\hline Oversight institutions & Budget rights & Pro-EU gov't & High debt & Outcome & Cases \\
\hline 1 & 0 & 1 & 0 & 1 & $\mathrm{EE}, \mathrm{LV}$ \\
\hline 1 & 0 & 0 & 1 & 1 & NL \\
\hline 0 & 1 & 0 & 1 & 1 & $\mathrm{EL}$ \\
\hline 1 & 1 & 0 & 1 & 1 & IT \\
\hline 1 & 0 & 1 & 1 & 1 & $\mathrm{SI}$ \\
\hline 0 & 1 & 1 & 1 & $1(\mathrm{C})$ & 1: AT, FR, PT. 0: ES. \\
\hline 1 & 0 & 0 & 0 & $0(C)$ & 1: DK. 0: FI, SK. \\
\hline 0 & 0 & 1 & 1 & 0 & $B E, I E$ \\
\hline 0 & 0 & 1 & 0 & 0 & LU \\
\hline 1 & 1 & 1 & 1 & 0 & DE \\
\hline
\end{tabular}

Note: Cyprus, Lithuania and Malta are excluded due to missing data on parliamentary budget rights.

(not shown) confirms that parliaments that lack institutional strength in at least one of these two areas do not, without exception, adapt institutionally to the European Semester. Thus, institutional strength-defined as strong rights in EU affairs or the budget-is another necessary condition for reform besides being in the Euro area or close to it.

A second finding is that debt, combined with institutional strength, and, possibly, reinforced by rather Eurosceptic governments (in Italy and the Netherlands), forms a sufficient path to reform in many cases. A possible interpretation is that reform depends on favorable institutional conditions and the enhanced monitoring and enforcement prospect that stems from high debt. The interpretation of the third combinationinstitutional strength and pro-EU governments-is less clear, however, as pro-EU governments have more commonly been seen as source of weak parliamentary adaptation to European integration.

Concerning the negative outcome, two conclusions can be drawn. First, as strong EU affairs institutions or budgetary rights are necessary for reform, their joint absence (i.e., institutional weakness) is by implication sufficient for the absence of reform. This implication (which can be confirmed in further analysis of the data) fits the path of Belgium, Ireland, and Luxembourg. It also implies that the third condition, pro-EU governments, can be eliminated from this path. It likely only remains as a result of the limited diversity of observed configura- tions. There is thus a sufficient path of institutional weakness explaining the lack of parliamentary oversight institutions for the European Semester.

Second, the paths to no reform also underline the limits of the institutional argument. Institutional strength is necessary for reform and institutional weakness is sufficient for no reform, but institutional strengths is unambiguously not sufficient for reform. This is in line with arguments highlighted earlier about the Finish parliament, which deemed reform unnecessary in light of the existence of a strong oversight system (Kreilinger, 2018; Rozenberg, 2017). The absence of debt might further explain the lack of reform in Finland (as well as Slovakia). The German case seems most puzzling given strong EU and budget institutions and noteworthy debt. One interpretation might be that such strong institutions, possibly reinforced by pro-EU governments, render reform unnecessary even if high debt enhances the prospect of entering the Semester's enforcement mechanisms.

One might ask whether selecting alternative or additional conditions would lead to different results. Given the limited membership of the Euro area, it should be kept in mind that adding conditions quickly exacerbates 'limited diversity' (unobserved configurations) and idiosyncrasy (all cases described by their own configurations). Yet, some key questions can be explored. First, opposition rather than governing parties might be decisive. However, replacing government with opposition EU support (the seat-weighted, average EU position of

Table 5. Results of the QCA.

\begin{tabular}{|c|c|}
\hline Positive outcome & Cases \\
\hline Oversight * budget * Pro-EU govt & $\mathrm{EE}, \mathrm{LV}, \mathrm{SI}$ \\
\hline Oversight $* \sim p r o-E U$ govt $*$ Debt & $\mathrm{IT}, \mathrm{NL}$ \\
\hline oversight $*$ Budget $*$ Debt & AT, FR, EL, PT. Inconsistent: ES. \\
\hline Negative outcome & Cases \\
\hline oversight $*$ budget $*$ Pro-EU govt & $B E, I E, L U$ \\
\hline Oversight $* \sim$ budget $* \sim$ pro-EU govt $* \sim d e b t$ & FI, SK. Inconsistent: DK. \\
\hline Oversight * Budget * Pro-EU govt * Debt & $\mathrm{DE}$ \\
\hline
\end{tabular}

Notes: Bold font denotes that a condition is present; The " ${ }^{\prime}$ symbol and italics denote the absence of a condition. 
all opposition parties, dichotomized at the mean) creates three evenly split, inconsistent configurations (not shown). Focusing on the opposition thus reduces our ability to distinguish parliaments that did or did not adapt to the European Semester.

Furthermore, the focus on debt as economic indicator could be criticized. The budget deficit holds an equally important place in the European Semester. Moreover, experience with EU conditionality in an ESM program might encourage parliamentary adaptation. Table 6 shows QCA results with the budget deficit replacing public debt as a condition. First, the main findings remain unaffected. For the positive and negative outcomes, the configurations are identical except for the debt and deficit conditions. A fourth path to the positive outcome, which however overlaps strongly with the third, is added but does not change the above conclusions regarding the relevance of institutions. However, whereas debt and institutional strength were found to form sufficient configurations in some cases, this is not consistently the case for the deficit. In general, the presence as well as the absence of excessive deficits is compatible with positive and negative outcomes. Second, Table A5 in the Supplementary File shows QCA results with past participation in an ESM program added as a condition. However, this analysis largely results in configurations in which the ESM condition, in its presence or absence, is simply appended to the previously found configurations, suggesting that it does not add to our ability to distinguish or systematize parliamentary reactions. This is likely due to the small number of countries having experienced an ESM program and the overall limited number of Euro area member states and countries.

\section{Conclusions}

Ever since the start of the European Semester, scholars have raised concerns about the input legitimacy and potentially detrimental effects of this process on national parliaments (Crum \& Merlo, 2020; Lord, 2017). The goal of this study has been to examine whether national parliaments address these concerns by adopting Semester-specific reforms of their domestic oversight procedures and rights. The focus was on whether Euro area parliaments might be more likely to adapt to the Semester and what might explain variation among Euro area countries. It was found that parliamentary adaptation to the European Semester has remained mixed with only some countries seeing reforms. In this respect, the picture remains similar to the early days of the Semester (Rittberger \& Winzen, 2015). Overall, parliamentary adaptation to the European Semester reflects existing divides related to differentiated integration and uneven institutional strength.

The analysis suggests new findings. First, two necessary conditions for reform were identified: Euro area membership and institutional strength. Together, these two conditions explain the lack of reform in 9 of (by 2019) 28 member states. Cyprus and Malta were excluded due to lack of data on budget rights, but it is often thought that these parliaments have weak institutions. If so, the absence of adaptation to the European Semester in these countries could possibly also be explained as above. This finding contributes new evidence to previous, albeit more behavioral, studies that disagree on the effect of Euro area membership (Hallerberg et al., 2018; Rasmussen, 2018).

Second, interpreting the effect of institutional strength in terms of necessity helps to resolve disagreement in the literature. Existing institutions might motivate reform, as commonly argued in the literature on national parliaments in the EU (Benz, 2004; Dimitrakopoulos, 2001), but might also render reform unnecessary, as indicated in the literature on the European Semester (Kreilinger, 2018; Rozenberg, 2017). This tension can be resolved if we think about existing institutions in terms of necessity. If parliaments lack institutional strength-evidenced by a lack of oversight procedures and rights in EU and budget matters-the path to adaptation to the European Semester is blocked. In contrast, if strong EU or budget oversight exists, adaptation becomes possible. Yet, whether reforms then occur, as in 9 countries, or not, as in Finland, Germany, and Slovakia, depends on further factors.

Third, the results regarding sufficient configurations for reform are more ambiguous. It appears that possible

Table 6. Results with the budget deficit instead of debt as a condition.

\begin{tabular}{|c|c|}
\hline Positive outcome & Cases \\
\hline Oversight $*$ budget $*$ Pro-EU govt & $\mathrm{EE}, \mathrm{LV}, \mathrm{SI}$ \\
\hline Oversight $* \sim$ pro-EU govt $*$ deficit & DK, IT, NL. Inconsistent: FI. \\
\hline$\sim$ oversight $*$ Budget $*$ Deficit & FR, EL, PT. Inconsistent: ES. \\
\hline oversight * Budget * Pro-EU govt & AT, FR, PT. Inconsistent: ES. \\
\hline Negative outcome & Cases \\
\hline >oversight $*$ budget $*$ Pro-EU govt & $B E, I E, L U$ \\
\hline Oversight $* \sim$ budget $* \sim$ pro-EU govt $*$ Deficit & SK \\
\hline Oversight $*$ Budget $*$ Pro-EU govt $*$ deficit & $\mathrm{DE}$ \\
\hline
\end{tabular}

Note: Bold font denotes that a condition is present. The ${ }^{\text {' }>}$ symbol and italics denote the absence of a condition. 
exposure to the Semester's enforcement procedures in countries with high debt might be sufficient for reform if institutional conditions are favorable. Yet, in several cases our ability to explain reform remains partial. These cases include Estonia, Latvia, and Slovenia, where institutional conditions are favorable, but it is not obvious what else motivated reform. Two deviant cases (Denmark and Spain) also remain. Regarding Denmark, Rasmussen (2018, p. 350) explains that parliamentarians grew dissatisfied with deficits of existing oversight mechanisms and specific Commission recommendations after two cycles of the European Semester and adopted more tailored rules. This is plausible, but it remains unclear from a comparative perspective why the same outcome did not obtain in, for example, Finland or Germany. Potentially, the compatibility of Commission recommendation with domestic policy preferences might play a role.

What are the wider implications? To begin with, if parliamentary oversight institutions are seen as indicator of input legitimacy, the results suggest a differentiated assessment of the input legitimacy of the European Semester. Within the Euro area, where the impact of the Semester is potentially highest, some institutionally strong parliaments have taken measures to adapt. Some parliaments have not implemented reforms but already have strong EU affair or budgetary rights. In contrast, the parliamentary deficit of the European Semester is clearest in the case of Euro area countries with institutionally weak parliaments. These parliaments are exposed to the Semester process and enforcement mechanisms but have not addressed domestic institutional weakness. Outside of the Euro area, parliaments have refrained from reforms, probably because the relevance of the European Semester without potential sanctions is ambiguous. Whether recent links made between the European Semester and the EU's Covid-19 response facility might change this pattern remains to be seen.

Whether the results indicate wider challenges beyond the European Semester can be debated. In an optimistic reading, they might imply that parliaments reform adequately given existing institutions and variation in the EU-level challenges that they face. In a more pessimistic reading, the results might imply that the deepening of integration widens the asymmetry between different parliaments within the Euro area and between the Euro area and less integrated countries (see also Benz, 2013; Rittberger \& Winzen, 2015). Some studies, including recent literature on the European Semester (Papadopoulos \& Piattoni, 2019), consider the limited involvement of (some) domestic actors such as parliaments in the EU as a normative and practical challenge.

Finally, it could be seen as a challenge that differentiated integration seems to lead to wider differences in how domestic institutions develop. A common argument is that differentiation, as practiced today, protects the unity of the EU's core institutions, both formally and in practice (Adler-Nissen, 2009; Dyson \& Marcussen, 2010; Schimmelfennig \& Winzen, 2020). This might reduce the true gap in exposure to EU policymaking between insiders and outsiders and could facilitate a return to uniform integration. It does not seem to be the case, however, that differentiation also preserves similarity in how domestic institutions engage with EU policymaking - rather, by reducing the relevance of EU processes for some member states, differentiated integration also reduces incentives for institutional adaptation. Domestic actors such as parliamentarians might thus end up less engaged-and, to the extent that engagement might foster support, less likely to support a return to uniform integration. These behavioral conjectures remain to be studied systematically, however.

\section{Acknowledgments}

I thank the editors and anonymous reviewers for helpful comments.

\section{Conflict of Interests}

The author declares no conflict of interests.

\section{Supplementary Material}

Supplementary material for this article is available online in the format provided by the author (unedited).

\section{References}

Adler-Nissen, R. (2009). Behind the scenes of differentiated integration: Circumventing national opt-outs in Justice and Home Affairs. Journal of European Public Policy, 16(1), 62-80. https://doi.org/10.1080/ 13501760802453239

Bakker, R., de Vries, C., Edwards, E., Hooghe, L., Jolly, S., Marks, G., Polk, J., Rovny, J., Steenbergen, M., \& Vachudova, M. A. (2015). Measuring party positions in Europe: The Chapel Hill expert survey trend file, 1999-2010. Party Politics, 21(1), 143-152. https:// doi.org/10.1177/1354068812462931

Bakker, R., Hooghe, L., Jolly, S., Marks, G., Polk, J., Rovny, J., Steenbergen, M., \& Vachudova, M. A. (2020). 2019 Chapel Hill Expert Survey. Version 1.2. [Data set]. Chapel Hill expert survey. chesdata.eu

Bauer, M. W., \& Becker, S. (2014). The unexpected winner of the crisis: The European Commission's strengthened role in economic governance. Journal of European Integration, 36(3), 213-229. https://doi. org/10.1080/07036337.2014.885750

Benz, A. (2004). Path-dependent institutions and strategic veto players: National parliaments in the European Union. West European Politics, 27(5), 875-900. https://doi.org/10.1080/0140238042000283283

Benz, A. (2013). An asymmetric two-level game: Parliaments in the Euro-Crisis. In B. Crum \& J. E. Fossum (Eds.), Practices of inter-parliamentary coordination in international politics (pp. 125-140). Routledge. 
Börzel, T. A. (2005). Mind the gap! European integration between level and scope. Journal of European Public Policy, 12(2), 217-236. https://doi.org/10.1080/ 13501760500043860

Crum, B. (2018). Parliamentary accountability in multilevel governance: What role for parliaments in postcrisis EU economic governance? Journal of European Public Policy, 25(2), 268-286. https://doi.org/ 10.1080/13501763.2017.1363270

Crum, B., \& Merlo, S. (2020). Democratic legitimacy in the post-crisis EMU. Journal of European Integration, 42(3), 399-413. https://doi.org/10.1080/07036337. 2020.1730347

Dawson, M. (2015). The legal and political accountability structure of 'post-crisis' EU economic governance. JCMS: Journal of Common Market Studies, 53(5), 976-993. https://doi.org/10.1111/jcms.12248

de Ruiter, R. (2010). EU soft law and the functioning of representative democracy: The use of methods of open co-ordination by Dutch and British parliamentarians. Journal of European Public Policy, 17(6), 874-890. https://doi.org/10.1080/13501763. 2010.486996

de Wilde, P., \& Raunio, T. (2018). Redirecting national parliaments: Setting priorities for involvement in EU affairs. Comparative European Politics, 16(2), 310-329. https://doi.org/10.1057/cep.2015.28

Dimitrakopoulos, D. G. (2001). Incrementalism and path dependence: European integration and institutional change in national parliaments. Journal of Common Market Studies, 39, 405-422. https://doi.org/ doi:10.1111/1468-5965.00296

Dyson, K., \& Marcussen, M. (2010). Transverse integration in European economic governance: Between unitary and differentiated integration. Journal of European Integration, 32(1), 17-39. https://doi.org/ 10.1080/07036330903375107

Fasone, C. (2014). European economic governance and parliamentary representation. What place for the European parliament? European Law Journal, 20(2), 164-185. https://doi.org/10.1111/eulj.12069

Folketinget. (2013). Consideration of the European Semester by the Danish parliament. (Report No. 5). European Affairs Committee and the Finance Committee.

Fromage, D. (2018). The European Parliament in the postcrisis era: An institution empowered on paper only? Journal of European Integration, 40(3), 281-294. https://doi.org/10.1080/07036337.2018.1450405

Genovese, F., \& Schneider, G. (2020). Smoke with fire: Financial crises and the demand for parliamentary oversight in the European Union. The Review of International Organizations, 15(3), 633-665. https://doi. org/10.1007/s11558-020-09383-0

Hallerberg, M., Marzinotto, B., \& Wolff, G. B. (2018). Explaining the evolving role of national parliaments under the European Semester. Journal of European Public Policy, 25(2), 250-267. https://doi.org/
10.1080/13501763.2017.1363273

Holzinger, K., \& Schimmelfennig, F. (2012). Differentiated integration in the European Union: Many concepts, sparse theory, few data. Journal of European Public Policy, 19(2), 292-305. https://doi.org/10.1080/ 13501763.2012 .641747

Interparliamentary Conference on Stability, Economic Coordination and Governance. (2015). Rules of procedure of the Interparliamentary Conference on Stability, Economic Coordination and Governance in the European Union. https://ipexl.secure.europarl. europa.eu

Kreilinger, V. (2018). Scrutinising the European Semester in national parliaments: What are the drivers of parliamentary involvement? Journal of European Integration, 40(3), 325-340. https://doi.org/10.1080/ 07036337.2018 .1450402

Lord, C. (2017). How can parliaments contribute to the legitimacy of the European Semester? Parliamentary Affairs, 70(4), 673-690. https://doi.org/10.1093/pa/ gsx017

Maatsch, A. (2017). Effectiveness of the European Semester: Explaining domestic consent and contestation. Parliamentary Affairs, 70(4), 691-709. https:// doi.org/10.1093/pa/gsx021

OECD. (2018). OECD International database of parliamentary budgeting practices. https://qdd.oecd.org/ subject.aspx?Subject=PBO_2018

Papadopoulos, Y., \& Piattoni, S. (2019). The European Semester: Democratic weaknesses as limits to learning. European Policy Analysis, 5(1), 58-79. https:// doi.org/10.1002/epa2.1060

Polk, J., Rovny, J., Bakker, R., Edwards, E., Hooghe, L., Jolly, S., Koedam, J., Kostelka, F., Marks, G., Schumacher, G., Steenbergen, M., Vachudova, M., \& Zilovic, M. (2017). Explaining the salience of antielitism and reducing political corruption for political parties in Europe with the 2014 Chapel Hill Expert survey data. Research \& Politics, 4(1). https://doi.org/ 10.1177/2053168016686915

Rasmussen, M. B. (2018). Accountability challenges in EU economic governance? Parliamentary scrutiny of the European Semester. Journal of European Integration, 40(3), 341-357. https://doi.org/10.1080/07036337. 2018.1451523

Raunio, T. (2005). Holding governments accountable in European affairs: Explaining cross-national variation. The Journal of Legislative Studies, 11(3/4), 319-342. https://doi.org/10.1080/13572330500348307

Raunio, T., \& Hix, S. (2000). Backbenchers learn to fight back: European integration and parliamentary government. West European Politics, 23(4), 142-168. https://doi.org/10.1080/01402380008425404

Rihoux, B., \& Ragin, C. C. (2009). Configurational comparative methods. SAGE.

Rittberger, B. (2003). The creation and empowerment of the European Parliament. Journal of Common Market Studies, 41, 203-225. https://doi.org/10.1111/1468- 
5965.00419

Rittberger, B., \& Winzen, T. (2015). Parlamentarismus nach der Krise: Die Vertiefung parlamentarischer Asymmetrie in der reformierten Wirtschafts- und Währungsunion [Parliamentarism after the crisis: The deepening of parliamentary asymmetry in the reformed Economic and Monetary Union]. Politische Vierteljahresschrift, 56(3), 430-456.

Rozenberg, O. (2017). The role of national parliaments in the EU after Lisbon: Potentialities and challenges. Directorate General for Internal Policies, Constitutional Affairs, European Parliament. https:// www.europarl.europa.eu/RegData/etudes/STUD/ 2017/583126/IPOL_STU(2017)583126_EN.pdf

Saalfeld, T. (2005). Deliberate delegation or abdication? Government backbenchers, ministers and European Union legislation. Journal of Legislative Studies, 11, 343-371. https://doi.org/10.1080/ 13572330500273547

Schimmelfennig, F., Leuffen, D., \& Rittberger, B. (2015). The European Union as a system of differentiated integration: Interdependence, politicization and differentiation. Journal of European Public Policy, 22(6), 764-782. https://doi.org/10.1080/13501763. 2015.1020835

Schimmelfennig, F., \& Winzen, T. (2020). Ever looser Union? Differentiated integration. Oxford University Press.

van der Veer, R. A., \& Haverland, M. (2018). Bread and butter or bread and circuses? Politicisation and the European Commission in the European Semester. European Union Politics, 19(3), 524-545. https://doi. org/10.1177/1465116518769753

Wehner, J. (2006). Assessing the power of the purse: An index of legislative budget institutions. Political Studies, 54(4), 767-785. https://doi.org/10.1111/j.14679248.2006.00628.x

Winzen, T. (2012). National parliamentary control of European Union affairs: A cross-national and longitudinal comparison. West European Politics, 35(3), 657-672. https://doi.org/10.1080/01402382. 2012.665745

Winzen, T. (2017). Constitutional preferences and parliamentary reform: Explaining national parliaments' adaptation to European integration. Oxford University Press.

Winzen, T. (2021). The institutional position of national parliaments in the European Union: Developments, explanations, effects. Journal of European Public Policy. https://doi.org/10.1080/13501763.2021. 1898663

Winzen, T., Roederer-Rynning, C., \& Schimmelfennig, F. (2015). Parliamentary co-evolution: National parliamentary reactions to the empowerment of the European Parliament. Journal of European Public Policy, 22(1), 75-93. https://doi.org/10.1080/13501763. 2014.881415

\section{About the Author}

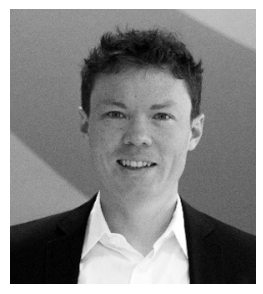

Thomas Winzen is a Senior Lecturer in the Department of Government at the University of Essex. $\mathrm{He}$ is interested in political institutions and how they can be reformed to contribute to democratic and legitimate governance in Europe and beyond. His research focuses on the role of parliaments in the European Union and in international affairs more broadly as well as on differentiated European integration. 